\title{
Study on the Injury and Rehabilitation of Racket Athletes with Disabilities
}

\author{
Zheng ChangSheng' ${ }^{1}$, Hwa-Kyung Shin ${ }^{2}$, Young sik Kim³ \\ 'Department of Physical Therapy, The Graduate School, Daegu Catholic University; ${ }^{2}$ Department of Physical Therapy, College of Bio and medical \\ science, The Graduate School, Daegu Catholic University; ${ }^{3}$ Korea Paralympic committee, Seoul, Korea
}

Purpose: This study examined the injury and rehabilitation of athletes with disabilities in racket sports projects (i.e., badminton, table tennis, and wheelchair tennis). In addition, the characteristics of each project and the differences among those projects are discussed.

Methods: Business team athletes with disabilities in racket sport were enrolled as subjects (i.e., 19 badminton athletes, 19 table tennis athletes, and 19 wheelchair tennis athletes). The real conditions of the injury, injury severity, injury site, symptoms, and rehabilitation methods after injury were analyzed.

Results: No significant differences were observed among the actual condition, injury severity, symptoms and the methods of rehabilitation on racket sport for athletes (i.e., badminton, table tennis, and wheelchair tennis athletes) with disability. The differences were focused mainly on the injury sites due to the characteristics of the different projects, and specific technical actions.

Conclusion: This study examined the real condition of the injury, injury severity, injury site, symptoms and rehabilitation methods after the injury on the rackets (i.e., badminton, table tennis, and wheelchair tennis) athletes with disabilities. The data can be used to eliminate the incidence of injury and minimize the injury severity for racket athletes with disabilities. In addition, it can also be used for the disabled, who like racket projects, as the fundamental material to prevent injury and assist in recovery.

Keywords: Athlete, Disabled persons, Injuries, Racquet sports, Rehabilitation.

\section{서 론}

현재 생활체육에 참여하는 장애인은 2007년부터 지속적으로 증가 하는 추세이다. 장애인 스포츠는 장애인의 독특한 요구를 충족시키 기 위하여 변형하거나 새로 개발한 운동을 의미한다. 여기서 독특한 요구란 어떠한 수행에 있어 정서적, 신체적, 정신적 문제로 필요한 사 항들이 존재할수 있는데, 이 필요 정도가 다른 사람보다 심하거나크 기 때문에 이를 극복할 수 있는 보충, 지원, 보완 등이 요구되는 경우 를 의미한다. 적당한 운동이 건강 증진에 좋다는 것은 이미 알려진 사실이지만, 장애인에게는 재활의 측면에서 의미가 더욱 크다고 할 수 있다. 적절한 스포츠는 장애인의 기능 감퇴를 예방할 수 있을 뿐만 아니라 근육의 질적 · 양적 변화를 일으키고, 호흡 · 순환 · 신경 기 능을 향상 시킬 수 있으며, 심리적 안정과 재활에 기여할 수 있다. ${ }^{3}$ 또 한 장애로 인해 손상된 자아를 회복하고, 동료 또는 지역사회와 상호 관계를 통하여 원만한 대인관계를 유지할 수 있다. 이를 통한 심리적
일체감은 장애인의 사회통합을 돕는 중요한 부분이 된다. ${ }^{4}$

그 중 탁구, 배드민턴, 휠체어테니스 등 라켓 종목은 상대적으로 신 체접촉이 많지 않아 안전 하고, 장소와상관없이 쉽게 접근할 수 있으 며. 시 · 운동 기능을 향상시킬 수 있다. ${ }^{5}$ 그러나 제한적인 공간에서 큰 관절가동범위에서의 급격한 감속과 가속으로 인한 팔의 손상은 심각한 문제점으로 대두되고 있다. ${ }^{6}$ 또한 빠른 경기 진행으로 인해 심 리적 스트레스가 높고, 특정 관절의 반복적인 움직임은 스포츠 손상 을 유발할 가능성이 높다.

스포츠 손상은 스포츠로 인한 모든 급성 또는 만성 신체적 손상 을 말하며, 외적 손상과 내적 손상으로 구분할 수 있다. 내적 손상이 란 신체내부의 힘에 의해 발생하는 손상이다. 과도한 훈련, 과도한 긴 장, 근육의 불균형, 유연성의 부족, 훈련방법 등이 원인이며, 훈련방법 을 개선하고 컨디션을 조절함으로써 대부분 예방이 가능하다. 한편, 외적 손상이란 외력에 의한 손상이다. 장비 및 시설의 불량 환경적인 결함, 그리고 신체검사의 결여 등이 주요 원인이며, 내적 손상과 마찬
Received Jul 1, 2019 Revised Aug 4, 2019

Accepted Aug 8, 2019

Corresponding author Hwa-Kyung Shin

E-mail hkshin1@cu.ac.kr
Copylight (02019 The Korean Society of Physical Therapy

This is an Open Access article distribute under the terms of the Creative Commons Attribution Non-commercial License (Http:// creativecommons.org/license/by-nc/4.O.) which permits unrestricted non-commercial use, distribution, and reproduction in any medium, provided the original work is properly cited. 
가지로 합리적인 훈련 방법의 개선과 컨디션 조절, 테이핑과 관절 보 호대를 사용하여 손상의 빈도와 심한 정도를 줄일 수 있다. 8

현재 과학기술의 발달로 안전을 고려한 생체역학적인 운동 장비가 개발되고 우수한 의료 서비스가 제공되고 있지만, 스포츠 손상의 발 생률을 줄이고 손상의 정도를 최소화하기 위한 방법이 요구된다고 생각한다. Choi와 Woo'는 스포츠 손상의 예방은 원인 및 치료방법을 분석하여 잘 응용하면 그 예방은 가능하다고 하였고 Lee 등 ${ }^{10}$ 은 스포 츠 손상의 발생과 재발의 예방을 성공적으로 수행하려면 손상의 원 인을 확인하고 교정해야 한다고 하였다. 또한 현재 스포츠 손상에 대 한 연구들은 대부분 비장애인 선수들을 대상으로 연구되어졌으나, 장애인 선수들을 대상으로 스포츠 손상 및 재활에 대한 연구들은 부족한 실정이다.

본 연구는 라켓 종목의 장애인 운동선수들을 대상으로 손상의 발 생 실태와 손상의 발생 부위, 손상의 급성 - 만성, 심각 정도, 증상 및 손상의 재활에 관하여 조사함으로써 스포츠 손상의 발생률을 줄이 고 부상의 정도를 최소화하기 위한 기초 자료를 제공하고자 한다.

\section{연구 방법}

\section{1. 연구대상}

본 연구는 대구와 부산에 거주하고 있는 장애인 실업팀 배드민턴, 탁 구, 휠체어테니스 선수에서 연구의 내용과 절차를 이해하고 설문조 사에 어려움이 없으며 연구의 목적을 알고 자발적으로 참여한 자 중 각 19 명, 총 57 명 지체장애인을 대상으로 조사를 실시하였다. 연구 대 상자의 일반적 특성은 Table 1 와 같다.

\section{2. 실험방법}

대구가톨릭대학교 연구윤리위원회(institutional review board, IRB)에 의뢰하여 승인(승인번호: CUIRB-2019-0003)을 받은 후 장애인 라켓 종목 운동선수들의 손상의 발생 실태와 손상의 급성 - 만성, 심각 정 도, 부위, 증상 및 손상의 재활 방법을 알아보기 위하여 운동 손상에 관한 선행연구에서 사용된 설문지 문항 중 본 연구의 내용과 관련된

Table 1. General characteristics subjects

\begin{tabular}{lccc}
\hline Factor & Badminton & Table tennis & Wheelchair tennis \\
\hline $\mathrm{N}$ & 19 & 19 & 19 \\
Age $(\mathrm{yr})$ & $47.0 \pm 9.4$ & $43.1 \pm 4.9$ & $49.5 \pm 5.4$ \\
Height $(\mathrm{cm})$ & $164.9 \pm 13.6$ & $175.3 \pm 4.2$ & $171.3 \pm 12.5$ \\
Weight $(\mathrm{kg})$ & $62.7 \pm 10.7$ & $63.4 \pm 9.7$ & $68.8 \pm 11.2$ \\
Ball age (yr) & $8.3 \pm 4.8$ & $16.2 \pm 5.8$ & $13.5 \pm 7.0$ \\
Session per week (n) & $3.8 \pm 1.1$ & $4.8 \pm 0.4$ & $4.4 \pm 1.1$ \\
Duration per exercise (h) & $3.2 \pm 1.3$ & $5.1 \pm 2.0$ & $4.6 \pm 1.8$ \\
\hline
\end{tabular}

$\mathrm{M} \pm \mathrm{SD}$ : Mean \pm standard deviation.
설문 문항을 기초로 하여 장애인 운동선수에 관한 연구의 목적에 맞 도록 수정 및 보완하였다.11-13 설문지의 구성은 일반적인 특성에 관한 설문 10 문항, 손상의 발생 실태에 관한 설문 6 문항 (발생원인, 발생시 기, 발생모드, 발생시간, 발생계절), 손상의 재활에 관한 설문 5 문항 (응급조치, 치료 기관, 치료형태, 치료방식, 치료기간)으로 구성 되었 고, 급 · 만성(급성만성), 심각 정도(약간, 중간, 심각), 부위, 증상(피부, 근육과 인대, 빼, 관절)에 관한 설문은 도표로 구성되어 있다. 설문지 를 완성 후 대구와 부산에 거주하고 있는 장애인 실업팀 라켓 종목 운동선수들을 모집하고 직접 방문하여 선수들의 휴식시간에 대상자 가자기평가기입법(self-administration)으로 작성하도록 하였다.

\section{3. 자료분석}

본 조사를 통하여 수집된 자료는 Window용 SPSS ver. 21 PASW statistics를 이용하여 분석하였다. 연구 대상자의 일반적 특성을 파악하기 위하여 기술통계를 실시하였다. 또한 라켓 종목 운동선수들의 각 문 항에 대한 빈도와 백분율을 제시하기 위하여 다중응답빈도분석 (multiple response analysis)을 실시하였다. 또한 손상의 발생빈도와 관 련설문지 세부항목과의 연관성을 검증을 통하여 통계적 $\chi^{2}(\mathrm{Chi}-$ square)법을 사용하였다. 통계적 유의수준은 $\alpha=0.05$ 로 설정하였다.

\section{결 과}

본 연구는 배드민턴, 탁구, 휠체어테니스와 같은 라켓 종목의 장애인 운동선수들을 대상으로 손상의 발생 실태와 손상의 발생 부위, 급 성·만성, 심각 정도, 증상 및 재활에 관하여 조사하였다.

배드민턴 선수의 손상의 발생 원인으로 과다 훈련이 높게 나타났 지만 유의한차이가 없었으며 $(\mathrm{p}>0.05)$, 실전 시합 중에 자주 발생했다 $(\mathrm{p}<0.05)$. 손상의 발생모드에서는 개인전과 단체전 간에 유의한 차이 가 없었고 $(\mathrm{p}>0.05)$, 오후에 많이 발생하며 $(\mathrm{p}<0.05)$, 겨울에 $(\mathrm{p}<0.05)$, 연습 훈련장에서 손상이 많이 발생하였다 $(\mathrm{p}<0.05)$ (Table 2). 경증이 $(\mathrm{p}<0.05)$, 급성 손상 $(\mathrm{p}<0.05)$ 가 유의하게 많았다(Table 3). 손상 부위 는 팔이 많았으며, 어깨, 팔꿈치, 손목의 순으로 나타났다 $(\mathrm{p}<0.05)$ (Table 4). 증상은 근육과 인대, 피부 찰과상이 많았다 $(\mathrm{p}<0.05)$, 근육, 인대, 뼈에서는 염증이 많이 나타났고 $(\mathrm{p}<0.05)$, 관절에서도 염증이 많이 나타났다 $(\mathrm{p}<0.05)$ (Table 3). 재활방법에서 응급조치로는 냉치료 $(\mathrm{p}<0.05)$, 치료 기관은 병원급 $(\mathrm{p}<0.05)$, 외래 치료 형태가 많이 나타났 다 $(\mathrm{p}<0.05)$. 많이 이용한 치료방식은 물리치료이고 $(\mathrm{p}<0.05)$, 치료기 간은 1-2주로 집중되어 나타났다( $<<0.05$ )(Table 5).

탁구 선수의 손상 발생실태에서도 과 훈련으로 인한 손상이 높게 나타났지만 유의한 차이가 없었고 $(\mathrm{p}>0.05)$, 발생시기는 실전 경기에 서 많이 나타났으며 $(\mathrm{p}<0.05)$, 개인전과 단체전 간에는 유의한 차이가 
없었다 $(\mathrm{p}>0.05)$. 오전에 손상이 많이 나타났다 $(\mathrm{p}<0.05)$. 손상이 많이 나타난 계절은 겨울이며 $(\mathrm{p}<0.05)$, 손상의 발생장소로는 연습 훈련장 에서 손상이 많았다 $(\mathrm{p}<0.05)($ Table 2$)$. 손상의 정도는 약한 정도의 손 상이 많이 나타났고 $(\mathrm{p}<0.05)$, 급성 손상이 많이 나타났다 $(\mathrm{p}<0.05)$ (Table 3). 손상 부위에서 손목, 팔꿈치, 어깨의 순으로 팔이 많이 나타 났다 $(\mathrm{p}<0.05)($ Table 4). 손상의 증상에서 근육과 인대에 손상이 많이 나타났다 $(\mathrm{p}<0.05)$. 피부에서 찰과상이 많이 나타났고 $(\mathrm{p}<0.05)$, 근육과
인대, 뼈, 관절에서 염증이 많이 나타났다 $(\mathrm{p}<0.05)$ (Table 3). 손상의 재 활방법으로 응급조치는 냉 치료( $\mathrm{p}<0.05)$, 치료 기관은 병원( $\mathrm{p}<0.05)$, 치료 형태는 외래 치료가 유의하게 많았다 $(\mathrm{p}<0.05)$. 치료 방식은 물리 치료 $(\mathrm{p}<0.05)$, 치료기간은 1-2 주가 많았다 $(\mathrm{p}<0.05)$ (Table 5).

훨체어테니스 선수의 손상의 발생 실태에서 체력부진으로 인한 경우가 많았으나 유의한 차이가 없었고( $p>0.05)$, 손상의 발생시기는 실전 경기 $(\mathrm{p}<0.05)$, 개인전에서 많았다 $(\mathrm{p}<0.05)$. 손상의 발생 시간은

Table 2. The tense of racket sports projects caused injury

\begin{tabular}{|c|c|c|c|c|c|c|c|c|c|}
\hline & \multirow{2}{*}{ Classification } & \multicolumn{2}{|c|}{$\begin{array}{l}\text { Badminton } \\
\quad(\mathrm{N}=19)\end{array}$} & \multicolumn{2}{|c|}{$\begin{array}{l}\text { Table tennis } \\
\quad(\mathrm{N}=19)\end{array}$} & \multicolumn{2}{|c|}{$\begin{array}{l}\text { Wheelchair tennis } \\
\qquad(\mathrm{N}=19)\end{array}$} & \multicolumn{2}{|c|}{$\begin{array}{c}\text { Total } \\
(\mathrm{N}=57)\end{array}$} \\
\hline & & Frequency & $\begin{array}{c}\text { Percentage } \\
(\%)\end{array}$ & Frequency & $\begin{array}{c}\text { Percentage } \\
(\%)\end{array}$ & Frequency & $\begin{array}{c}\text { Percentage } \\
(\%)\end{array}$ & Frequency & $\begin{array}{c}\text { Percentage } \\
(\%)\end{array}$ \\
\hline \multirow[t]{9}{*}{ Cause } & Physically tired & 1.000 & 5.260 & 2.000 & 10.530 & 6.000 & 31.580 & 9.000 & 15.790 \\
\hline & Not notice & 3.000 & 15.790 & 0.000 & 0.000 & 5.000 & 26.320 & 8.000 & 14.040 \\
\hline & Equipment defects & 0.000 & 0.000 & 0.000 & 0.000 & 2.000 & 10.530 & 2.000 & 3.510 \\
\hline & Technical problems & 6.000 & 31.580 & 6.000 & 31.580 & 0.000 & 0.000 & 12.000 & 21.050 \\
\hline & Insufficient preparation & 1.000 & 5.260 & 0.000 & 0.000 & 2.000 & 10.530 & 3.000 & 5.260 \\
\hline & Overload training & 8.000 & 42.110 & 9.000 & 47.370 & 4.000 & 21.050 & 21.000 & 36.840 \\
\hline & Too nervous & 0.000 & 0.000 & 2.000 & 10.530 & 0.000 & 0.000 & 2.000 & 3.510 \\
\hline & $X^{2}$ & 4.789 & & 2.000 & & 0.579 & & 22.474 & \\
\hline & $p$ & 0.188 & & 0.368 & & 0.901 & & $0.000^{*}$ & \\
\hline \multirow[t]{5}{*}{ Opportunity } & Physical training & 4.000 & 21.050 & 2.000 & 10.530 & 4.000 & 21.050 & 10.000 & 17.540 \\
\hline & Technology practice & 2.000 & 10.530 & 5.000 & 26.320 & 3.000 & 15.790 & 10.000 & 17.540 \\
\hline & Actual combat & 13.000 & 68.420 & 12.000 & 63.160 & 12.000 & 63.160 & 37.000 & 64.910 \\
\hline & $X^{2}$ & 10.842 & & 8.316 & & 7.684 & & 5.070 & \\
\hline & $\mathrm{p}$ & $0.004^{*}$ & & $0.016^{\star}$ & & $0.021^{*}$ & & $0.024^{*}$ & \\
\hline \multirow[t]{4}{*}{ Mode } & Singles & 10.000 & 52.630 & 11.000 & 57.890 & 15.000 & 78.950 & 36.000 & 63.160 \\
\hline & Group & 9.000 & 47.370 & 8.000 & 42.110 & 4.000 & 21.050 & 21.000 & 36.840 \\
\hline & $X^{2}$ & 0.053 & & 0.474 & & 6.368 & & 3.947 & \\
\hline & $\mathrm{p}$ & 0.819 & & 0.491 & & $0.012^{*}$ & & $0.047^{\star}$ & \\
\hline \multirow[t]{6}{*}{ Time } & Dawn & 0.000 & 0.000 & 0.000 & 0.000 & 1.000 & 5.260 & 1.000 & 1.750 \\
\hline & Morning & 4.000 & 21.050 & 12.000 & 63.160 & 10.000 & 52.630 & 26.000 & 45.610 \\
\hline & Afternoon & 13.000 & 68.420 & 6.000 & 31.580 & 8.000 & 42.110 & 27.000 & 47.370 \\
\hline & Evening & 2.000 & 10.530 & 1.000 & 5.260 & 0.000 & 0.000 & 3.000 & 5.260 \\
\hline & $X^{2}$ & 10.842 & & 9.597 & & 7.053 & & 42.298 & \\
\hline & $p$ & $0.004^{*}$ & & $0.008^{*}$ & & $0.029^{*}$ & & $0.000^{*}$ & \\
\hline \multirow[t]{6}{*}{ Season } & Spring & 2.000 & 10.530 & 1.000 & 5.260 & 2.000 & 10.530 & 5.000 & 8.770 \\
\hline & Summer & 3.000 & 15.790 & 4.000 & 21.050 & 4.000 & 21.050 & 11.000 & 19.300 \\
\hline & Fall & 1.000 & 5.260 & 3.000 & 15.790 & 5.260 & 8.770 & 5.000 & 8.770 \\
\hline & Winter & 13.000 & 68.420 & 11.000 & 57.890 & 63.160 & 63.160 & 36.000 & 63.160 \\
\hline & $X^{2}$ & 19.526 & & 11.947 & & 15.737 & & 22.842 & \\
\hline & $p$ & $0.000^{*}$ & & $0.008^{*}$ & & $0.001^{*}$ & & $0.000^{*}$ & \\
\hline \multirow[t]{5}{*}{ Site } & Competition field & 5.000 & 26.320 & 3.000 & 15.790 & 4.000 & 21.050 & 12.000 & 21.050 \\
\hline & Training ground & 12.000 & 63.160 & 15.000 & 78.950 & 13.000 & 68.420 & 40.000 & 79.180 \\
\hline & Physical training ground & 2.000 & 10.530 & 1.000 & 5.260 & 2.000 & 10.530 & 5.000 & 8.770 \\
\hline & $X^{2}$ & 8.316 & & 18.105 & & 10.842 & & 36.105 & \\
\hline & $\mathrm{p}$ & $0.016^{*}$ & & $0.000^{*}$ & & $0.004^{*}$ & & $0.000^{*}$ & \\
\hline
\end{tabular}

${ }^{*} p<0.05$ 
Table 3. The symptoms and extent of injury caused by racket sports projects

\begin{tabular}{|c|c|c|c|c|c|c|c|c|c|}
\hline \multirow{2}{*}{ Classification } & & \multicolumn{2}{|c|}{$\begin{array}{l}\text { Badminton } \\
(N=19)\end{array}$} & \multicolumn{2}{|c|}{$\begin{array}{l}\text { Table tennis } \\
\quad(\mathrm{N}=19)\end{array}$} & \multicolumn{2}{|c|}{$\begin{array}{l}\text { Wheelchair tennis } \\
\qquad(N=19)\end{array}$} & \multicolumn{2}{|c|}{$\begin{array}{l}\text { Total } \\
(\mathrm{N}=57)\end{array}$} \\
\hline & & Frequency & $\begin{array}{l}\text { Percentage } \\
(\%)\end{array}$ & Frequency & $\begin{array}{l}\text { Percentage } \\
(\%)\end{array}$ & Frequency & $\begin{array}{l}\text { Percentage } \\
\quad(\%)\end{array}$ & Frequency & $\begin{array}{l}\text { Percentage } \\
\quad(\%)\end{array}$ \\
\hline \multirow[t]{5}{*}{ Skin } & Blister & 2.000 & 12.500 & 4.000 & 36.360 & 6.000 & 40.000 & 12.000 & 28.570 \\
\hline & Abrasion & 13.000 & 81.250 & 6.000 & 54.550 & 7.000 & 46.670 & 26.000 & 61.900 \\
\hline & Furuncle & 1.000 & 6.250 & 1.000 & 9.090 & 2.000 & 13.330 & 4.000 & 9.520 \\
\hline & $x^{2}$ & 16.625 & & 3.455 & & 2.800 & & 17.714 & \\
\hline & $\mathrm{p}$ & $0.000^{*}$ & & 0.178 & & 0.247 & & $0.000^{*}$ & \\
\hline \multirow[t]{7}{*}{ Muscle ligament } & Inflammation & 104.000 & 63.410 & 173.000 & 75.220 & 85.000 & 52.800 & 362.000 & 65.230 \\
\hline & Contusion & 12.000 & 7.320 & 15.000 & 6.520 & 49.000 & 30.430 & 76.000 & 13.690 \\
\hline & Myorrhexis & 8.000 & 4.880 & 5.000 & 2.170 & 3.000 & 1.860 & 16.000 & 2.880 \\
\hline & Convulsion & 23.000 & 14.020 & 18.000 & 7.830 & 16.000 & 9.940 & 57.000 & 10.270 \\
\hline & Distortion & 17.000 & 10.370 & 19.000 & 8.260 & 8.000 & 4.970 & 44.000 & 7.930 \\
\hline & $x^{2}$ & 197.037 & & 440.957 & & 148.161 & & 726.631 & \\
\hline & $\mathrm{p}$ & $0.000^{*}$ & & $0.000^{*}$ & & $0.000^{*}$ & & $0.000^{*}$ & \\
\hline \multirow[t]{5}{*}{ Bone } & Inflammation & 86.000 & 88.660 & 67.000 & 81.710 & 34.000 & 75.560 & 187.000 & 83.480 \\
\hline & Fracture & 8.000 & 8.250 & 6.000 & 7.320 & 7.000 & 15.560 & 21.000 & 9.380 \\
\hline & Cartilage hurts & 3.000 & 3.090 & 9.000 & 10.980 & 4.000 & 8.890 & 16.000 & 7.140 \\
\hline & $x^{2}$ & 134.000 & & 86.512 & & 36.400 & & 253.67 & \\
\hline & $\mathrm{p}$ & $0.000^{*}$ & & $0.000^{*}$ & & $0.000^{*}$ & & $0.000^{*}$ & \\
\hline \multirow[t]{6}{*}{ Joint } & Inflammation & 10.000 & 58.820 & 24.000 & 70.590 & 19.000 & 65.520 & 53.000 & 66.250 \\
\hline & Disc & 4.000 & 23.530 & 2.000 & 5.880 & 1.000 & 3.450 & 7.000 & 8.750 \\
\hline & Joint changes & 2.000 & 11.760 & 7.000 & 20.590 & 7.000 & 24.140 & 16.000 & 20.000 \\
\hline & Dislocation & 1.000 & 5.880 & 1.000 & 2.940 & 2.000 & 6.900 & 4.000 & 5.000 \\
\hline & $x^{2}$ & 11.471 & & 40.118 & & 28.241 & & 76.500 & \\
\hline & $\mathrm{p}$ & $0.009^{*}$ & & $0.000^{*}$ & & $0.000^{*}$ & & $0.000^{*}$ & \\
\hline \multirow[t]{4}{*}{ Acute or chronic } & Acute & 183.000 & 62.240 & 230.000 & 64.430 & 179.000 & 71.600 & 592.000 & 65.700 \\
\hline & Chronic & 111.000 & 37.760 & 127.000 & 35.570 & 71.000 & 28.400 & 309.000 & 34.300 \\
\hline & $x^{2}$ & 17.633 & & 29.717 & & 46.656 & & 88.889 & \\
\hline & $p$ & $0.000^{*}$ & & $0.000^{*}$ & & $0.000^{*}$ & & $0.000^{*}$ & \\
\hline \multirow[t]{5}{*}{ Severity } & Slight & 160.000 & 54.420 & 163.000 & 45.660 & 150.000 & 60.000 & 473.000 & 52.500 \\
\hline & Medium & 109.000 & 37.070 & 114.000 & 31.930 & 76.000 & 30.400 & 299.000 & 33.190 \\
\hline & Serious & 25.000 & 8.500 & 80.000 & 22.410 & 24.000 & 9.600 & 129.000 & 14.320 \\
\hline & $x^{2}$ & 94.837 & & 29.261 & & 96.224 & & 197.017 & \\
\hline & $p$ & $0.000^{*}$ & & $0.000^{*}$ & & $0.000^{*}$ & & $0.000^{*}$ & \\
\hline
\end{tabular}

${ }^{*} p<0.05$

오전에 $(\mathrm{p}<0.05)$, 계절은 겨울에 $(\mathrm{p}<0.05)$, 발생 장소는 연습 훈련장이 많았다 $(\mathrm{p}<0.05)$ (Table 2). 손상의 정도는 급성과 $(\mathrm{p}<0.05)$, 경증의 손상 이 많았다 $(\mathrm{p}<0.05)$ (Table 3). 훨체어테니스 선수도 팔의 손상이 많았 는데, 팔꿈치, 어깨, 손목의 순이었다 $(\mathrm{p}<0.05)(T a b l e ~ 4)$. 증상은 마찬가 지로 근육과 인대에서 많았고 $(\mathrm{p}<0.05)$, 피부의 찰과상이 많았고 $(\mathrm{p}<0.05)$, 근육과 인대, 빼, 관절에서는 모두 염증이 많이 나타났다 $(\mathrm{p}<0.05)$ (Table 3). 재활방법에서 응급치료로 냉치료 $(\mathrm{p}<0.05)$, 치료 기 관은 병원이 많이 나타났으며 $(\mathrm{p}<0.05)$, 치료형태로는 주로 외래치료 $(\mathrm{p}<0.05)$. 많이 이용하는 치료 방식은 물리치료 $(\mathrm{p}<0.05)$, 치료기간은 1-2주였다 $(\mathrm{p}<0.05)$ (Table 5).

\section{고 찰}

본 연구는 라켓 종목의 장애인 운동선수들을 대상으로 손상의 발생 실태와 손상의 발생 부위, 손상의 급성 - 만성, 심각 정도, 증상 및 손 상의 재활에 관하여 조사하였다. 손상의 발생실태에서 배드민턴과 탁구 선수는 과 훈련의 원인으로 손상을 가장 많이 입은 것으로 나 타났다. $\mathrm{Choi}^{14}$ 의 연구에서도 국가대표선수들의 과도한 훈련이 운동 손상의 주된 원인으로 나타났고, $\operatorname{Kim}{ }^{15}$ 은 과도한 훈련으로 인한 경미한 손상이 지속되면 만성질환으로 발전될 수 있으며, 회복 후에 도 운동 기술과 체력의 저하로 이어질 수 있다고 보고하였다. 본 연구 
Table 4. The injury site caused by racket sports projects

\begin{tabular}{|c|c|c|c|c|c|c|c|c|c|}
\hline \multirow{2}{*}{ Classification } & & \multicolumn{2}{|c|}{$\begin{array}{l}\text { Badminton } \\
(N=19)\end{array}$} & \multicolumn{2}{|c|}{$\begin{array}{l}\text { Table tennis } \\
(\mathrm{N}=19)\end{array}$} & \multicolumn{2}{|c|}{$\begin{array}{l}\text { Wheelchair tennis } \\
\qquad(N=19)\end{array}$} & \multicolumn{2}{|c|}{$\begin{array}{l}\text { Total } \\
(\mathrm{N}=57)\end{array}$} \\
\hline & & Frequency & $\begin{array}{l}\text { Percentage } \\
(\%)\end{array}$ & Frequency & $\begin{array}{c}\text { Percentage } \\
\text { (\%) }\end{array}$ & Frequency & $\begin{array}{l}\text { Percentage } \\
(\%)\end{array}$ & Frequency & $\begin{array}{c}\text { Percentage } \\
(\%)\end{array}$ \\
\hline \multirow[t]{5}{*}{ Head and neck } & Head & 3.000 & 21.430 & 2.000 & 11.760 & 7.000 & 38.890 & 12.000 & 24.490 \\
\hline & Face & 4.000 & 28.570 & 3.000 & 17.650 & 2.000 & 11.110 & 9.000 & 18.370 \\
\hline & Neck & 7.000 & 50.000 & 12.000 & 70.590 & 9.000 & 50.000 & 28.000 & 57.140 \\
\hline & $x^{2}$ & 1.857 & & 10.706 & & 4.333 & & 12.776 & \\
\hline & $\mathrm{p}$ & 0.395 & & $0.005^{*}$ & & 0.115 & & $0.002^{*}$ & \\
\hline \multirow[t]{9}{*}{ Upper limb } & Shoulder & 108.000 & 41.700 & 61.000 & 21.710 & 43.000 & 22.400 & 212.000 & 28.960 \\
\hline & Upper arm & 5.000 & 1.930 & 16.000 & 5.690 & 11.000 & 5.730 & 32.000 & 4.370 \\
\hline & Elbow & 71.000 & 27.410 & 69.000 & 24.560 & 89.000 & 46.350 & 229.000 & 31.280 \\
\hline & Lower arm & 9.000 & 3.470 & 11.000 & 3.910 & 17.000 & 8.850 & 37.000 & 5.050 \\
\hline & Wrist & 51.000 & 19.690 & 113.000 & 40.210 & 19.000 & 9.900 & 183.000 & 25.000 \\
\hline & Hand & 5.000 & 1.930 & 6.000 & 2.140 & 6.000 & 3.130 & 17.000 & 2.320 \\
\hline & Finger & 10.000 & 3.860 & 5.000 & 1.780 & 7.000 & 3.650 & 22.000 & 3.010 \\
\hline & $x^{2}$ & 194.753 & & 259.295 & & 195.406 & & 549.803 & \\
\hline & $\mathrm{p}$ & $0.000^{*}$ & & $0.000^{*}$ & & $0.000^{*}$ & & $0.000^{*}$ & \\
\hline \multirow[t]{6}{*}{ Body } & Chest & 1.000 & 9.090 & 32.000 & 68.090 & 12.000 & 38.710 & 45.000 & 50.560 \\
\hline & Back & 5.000 & 45.450 & 2.000 & 4.260 & 10.000 & 32.260 & 17.000 & 19.100 \\
\hline & Abdomen & 2.000 & 18.180 & 4.000 & 8.510 & 4.000 & 12.900 & 10.000 & 11.240 \\
\hline & Waist & 3.000 & 27.270 & 9.000 & 19.150 & 5.000 & 16.130 & 17.000 & 19.100 \\
\hline & $x^{2}$ & 3.182 & & 48.745 & & 5.774 & & 21.596 & \\
\hline & $\mathrm{p}$ & 0.364 & & $0.000^{*}$ & & 0.123 & & $0.000^{*}$ & \\
\hline \multirow[t]{9}{*}{ Lower limb } & Hip & 2.000 & 20.000 & 5.000 & 41.670 & 2.000 & 22.220 & 9.000 & 29.030 \\
\hline & Upper knee & 1.000 & 10.000 & 1.000 & 8.330 & 2.000 & 22.220 & 4.000 & 12.900 \\
\hline & Knee & 0.000 & 0.000 & 0.000 & 0.000 & 1.000 & 11.110 & 1.000 & 3.230 \\
\hline & Lower knee & 0.000 & 0.000 & 0.000 & 0.000 & 1.000 & 11.110 & 1.000 & 3.230 \\
\hline & Ankle & 7.000 & 70.000 & 6.000 & 50.000 & 1.000 & 11.110 & 14.000 & 45.160 \\
\hline & Foot & 0.000 & 0.000 & 0.000 & 0.000 & 1.000 & 11.110 & 1.000 & 3.230 \\
\hline & Toe & 0.000 & 0.000 & 0.000 & 0.000 & 1.000 & 11.110 & 1.000 & 3.230 \\
\hline & $x^{2}$ & 6.200 & & 3.500 & & 0.111 & & 8.871 & \\
\hline & $\mathrm{p}$ & $0.045^{*}$ & & 0.174 & & 0.739 & & $0.031^{*}$ & \\
\hline
\end{tabular}

${ }^{*} p<0.05$.

의 훨체어테니스 선수에서도 체력 부진이 스포츠 손상의 가장 큰 원 인으로 나타났다. 훈련의 시간, 빈도, 강도 즉 체력에 합리적인 운동 량을 조절하여 과다 훈련과 체력부진으로 인한 스포츠 손상을 예방 할 필요가 있다. 세 종목 모두 실전경기에서 이기기 위하여 파괴력이 있는 운동 기술을 수행하는 동안 스포츠 손상이 많을 수밖에 없다. ${ }^{14}$ 격렬한 실전시합에서 체력소모가 크고, 장기간의 정신집중으로 인 한 피로와 동작의 변형으로 손상을 더 쉽게 입을 수 있다. 또한 훨체 어테니스 선수는 단체전보다 개인전에서 손상을 많이 입는 것으로 나타났다. 단체전은 훨체어의 이동범위가 작지만 단독으로 하는 개 인 경기는 상대적으로 큰 범위에서 이동하기에 손상이 크다고 볼 수 있다. 세 종목의 운동선수는 모두 겨울에 손상을 많이 입은 것으로 나타났는데, 이는 낮은 기온은 신경, 근육조직의 기능저하를 초래할
수 있기 때문이다. ${ }^{12}$ 신경, 근육조직의 기능을 정상적으로 수행하기 위하여 충분한 준비 운동을 통하여 몸의 열을 발생시킨 다음, 본 운 동을 시작하는 것이 손상을 예방할 수 있을 것으로 본다. ${ }^{13}$ 또한 세 종 목의 운동선수는 모두 연습 훈련장에서 손상을 많이 입은 것으로 나타났다. 이는 연습 훈련장은 많은 실전 시합과 반복적인 기술을 연 습하고, 피로가 많이 발생하는 곳이기에 손상이 많이 발생하는 장소 였던 것으로 보인다. 또한, 세 종목은 모두 급성 손상이 많았다. 비록 만성 손상은 상대적으로 적게 나타났지만, 급성기 동안 완전히 치료 가 되지 않으면 만성질환으로 이어질 수 있기 때문에 운동선수들은 항상 본인의 손상에 대한 상태를 잘 파악하고, 완전히 치료된 후 운 동을 시작할 것을 추천한다.

세 종목 모두 팔에서 손상이 많은 것으로 나타났다. 비장애인 운 
Table 5. Symptoms of racket sports projects injuries

\begin{tabular}{|c|c|c|c|c|c|c|c|c|c|}
\hline \multirow{2}{*}{ Classification } & & \multicolumn{2}{|c|}{ Badminton $(\mathrm{N}=19)$} & \multicolumn{2}{|c|}{ Table tennis $(\mathrm{N}=19)$} & \multicolumn{2}{|c|}{$\begin{array}{l}\text { Wheelchair tennis } \\
\qquad(N=19)\end{array}$} & \multicolumn{2}{|c|}{ Total $(\mathrm{N}=57)$} \\
\hline & & Frequency & $\begin{array}{l}\text { Percentage } \\
(\%)\end{array}$ & Frequency & $\begin{array}{l}\text { Percentage } \\
(\%)\end{array}$ & Frequency & $\begin{array}{l}\text { Percentage } \\
(\%)\end{array}$ & Frequency & $\begin{array}{c}\text { Percentage } \\
(\%)\end{array}$ \\
\hline \multirow[t]{7}{*}{ Emergency measure } & $\mathrm{CT}$ & 14.000 & 73.680 & 13.000 & 68.420 & 10.000 & 52.630 & 37.000 & 64.910 \\
\hline & Thermotherapy & 1.000 & 5.260 & 2.000 & 10.530 & 3.000 & 15.790 & 6.000 & 10.530 \\
\hline & Movement & 1.000 & 5.260 & 4.000 & 21.050 & 5.000 & 26.320 & 10.000 & 17.540 \\
\hline & Ointment & 3.000 & 15.790 & 0.000 & 0.000 & 0.000 & 0.000 & 3.000 & 5.260 \\
\hline & Bandage & 0.000 & 0.000 & 0.000 & 0.000 & 1.000 & 5.260 & 1.000 & 1.750 \\
\hline & $x^{2}$ & 14.000 & & 10.842 & & 9.421 & & 75.895 & \\
\hline & $\mathrm{p}$ & $0.001^{*}$ & & $0.004^{*}$ & & $0.024^{*}$ & & $0.000^{*}$ & \\
\hline \multirow[t]{5}{*}{ Treatment agencies } & Hospital & 11.000 & 57.890 & 12.000 & 63.160 & 11.000 & 57.890 & 34.000 & 59.650 \\
\hline & OMC & 1.000 & 5.260 & 2.000 & 10.530 & 2.000 & 10.530 & 5.000 & 8.770 \\
\hline & ST & 7.000 & 36.840 & 5.000 & 26.320 & 6.000 & 31.580 & 18.000 & 31.580 \\
\hline & $x^{2}$ & 8.000 & & 8.316 & & 6.421 & & 22.211 & \\
\hline & $\mathrm{p}$ & $0.018^{*}$ & & $0.016^{*}$ & & $0.040^{*}$ & & $0.000^{*}$ & \\
\hline \multirow[t]{5}{*}{ Form of treatment } & Hospitalized & 4.000 & 21.050 & 1.000 & 5.260 & 3.000 & 15.790 & 8.000 & 14.040 \\
\hline & External treatment & 13.000 & 68.420 & 14.000 & 73.680 & 14.000 & 73.680 & 41.000 & 71.930 \\
\hline & Team doctor & 2.000 & 10.530 & 4.000 & 21.050 & 2.000 & 10.530 & 8.000 & 14.040 \\
\hline & $x^{2}$ & 10.842 & & 14.632 & & 14.000 & & 10.965 & \\
\hline & $\mathrm{p}$ & $0.004^{*}$ & & $0.001^{*}$ & & $0.001^{*}$ & & $0.001^{*}$ & \\
\hline \multirow[t]{7}{*}{ Therapeutic method } & Physiotherapy & 11.000 & 57.890 & 13.000 & 68.420 & 10.000 & 52.630 & 34.000 & 59.650 \\
\hline & Rest & 3.000 & 15.790 & 3.000 & 15.790 & 4.000 & 21.050 & 10.000 & 17.540 \\
\hline & OMCT & 2.000 & 10.530 & 2.000 & 10.530 & 2.000 & 10.530 & 6.000 & 10.530 \\
\hline & SM & 1.000 & 5.260 & 1.000 & 5.260 & 3.000 & 15.790 & 5.000 & 8.770 \\
\hline & APAD & 2.000 & 10.530 & 0.000 & 0.000 & 0.000 & 0.000 & 2.000 & 3.510 \\
\hline & $x^{2}$ & 11.947 & & 19.526 & & 8.158 & & 58.877 & \\
\hline & $\mathrm{p}$ & $0.008^{*}$ & & $0.000^{*}$ & & $0.043^{*}$ & & $0.000^{*}$ & \\
\hline \multirow[t]{6}{*}{ Treatment period } & Within a week & 3.000 & 15.790 & 2.000 & 10.530 & 3.000 & 15.790 & 8.000 & 14.040 \\
\hline & One to two weeks & 10.000 & 52.630 & 10.000 & 52.630 & 11.000 & 57.890 & 31.000 & 54.390 \\
\hline & Three to four weeks & 4.000 & 21.050 & 3.000 & 15.790 & 3.000 & 15.790 & 10.000 & 17.540 \\
\hline & More than four weeks & 2.000 & 10.530 & 4.000 & 21.050 & 2.000 & 10.530 & 8.000 & 14.040 \\
\hline & $x^{2}$ & 8.158 & & 8.158 & & 6.421 & & 12.326 & \\
\hline & $p$ & $0.045^{*}$ & & $0.043^{*}$ & & $0.040^{*}$ & & $0.002^{*}$ & \\
\hline
\end{tabular}

CT: cold treatement, OMC: oriental medical clinic, ST: self-treatment, OMCT: oriental medical clinic for treatment, SM: sports massage, APAD: apply a plaster or anti-inflammatory drug, ${ }^{*} p<0.05$.

동선수의 경우는 발의 빠른 움직임, 민첩한 방향 전환, 급작스런 정지 동작 등의 원인으로 다리, 특히 발목 부위의 손상이 많이 발생한 다.1718 그러나라켓 종목 선수는 대부분 지체 장애인이며 휠체어를 사 용하며, 횔체어에 다리를 고정하고 보호하는 안정장치가 있기 때문 에 장애인 운동선수의 손상 부위는 팔에 집중되어 나타났다. 손상이 집중된 팔부위를 밨을 때 배드민턴 선수에서 어깨, 팔꿈치, 손목의 순 으로 나타났고, 탁구 선수에서 손목, 팔꿈치, 어깨의 순으로 나타났으 며, 훨체어테니스 선수에서 팔꿈치, 어깨, 손목의 순으로 나타났다. 운 동선수들의 팔부위의 손상빈도분포를 봤을때 Lee ${ }^{11}$ 의 배드민턴 운동 선수에 관한 연구와 거의 일치하게 나타났지만, Song ${ }^{12}$ 의 테니스 운동 선수와 Lee ${ }^{13}$ 의 탁구 운동선수에 관한연구와는 차이가 나타났다. 배
드민턴과 횔체어테니스 선수의 어깨부위에서 손상이 탁구 선수 보다 많이 나타난 원인은 배드민턴과 횔체어테니스의 동작은 위에서 아래 로 내리치는 형태를 취하고 라켓의 무게가 상대적으로 무거운 반면, 탁구의 동작은 아래서 위로 감아 올려치는 형태뿐만 아니라 라켓의 무게도 가볍기 때문이다. ${ }^{13}$ 그리고 팔꿈치 손상은 테니스 운동 손상 중 흔히 나타나는 손상인데 주로 팔꿈치에 장기간 스트레스가 누적 됨으로 인한 테니스 엘보로 생각된다. 또한 탁구의 기술적인 동작은 주로 팔을 돌려 손목으로 힘을 주기에 동작의 미세한 변형이라도 손 목 부위에 손상을 쉽게 입을 수 있다.

손상의 증상을 살펴보면 배드민턴, 탁구, 횔체어테니스 세 종목의 선수가 모두 근육 · 인대에 손상을 많이 입은 것으로 나타났다. 자신 
의 체력과 무관하게 높은 강도의 운동을 실시하면 근육조직 손상이 발생할 가능성이 높아진다. ${ }^{19} \mathrm{Park}^{20}$ 등의 연구에서도 강도 높은 운동 의 형태로 적혈구 용혈과 근육 손상 지표가 높게 나타나는 것으로 보 고되었다. 근육 - 인대의 손상이 많이 나타나기 때문에 주 운동을 하 기 전에 근육 - 인대의 긴장을 풀어주는 준비운동이 필요하다고 생 각된다. 특정 보호 장비를 사용할 수 있는데, 특히 탄성 테이핑은 통 증감소, 근육 불균형 감소, 피부수용기 자극을 통한 근육 흥분성을 증진하고, 근 피로를 감소시킬 수 있다고 보고되었다. ${ }^{21}$ 피부 증상으 로 세 종목 선수는 모두 찰과상이 많이 나타났다. 운동 중 상대방에 서 오는 빠른 구기와 긴장감은 경기 중 횔체어의 잘못된 조작으로 찰 과상을 입게 된다. 근육 · 인대, 빼, 관절에서 모두 염증이 많이 나타 났는데, 라켓 종목의 특성으로 투기종목이나 구기종목과는 달리 신 체접촉이 거의 없기 때문에 외부 접촉에 의한 손상보다 내적인 손상 이 많이 입게 된다. 반복적으로 근육에 부하가 발생하기에 근육의 과 도한 활동, 인대의 긴장, 관절의 해부학적 변화로 통증을 초래하고, 반 복성이 높은 운동동작과 기술적인 특정 움직임은 통증을 악화시키 고 관절의 원활한 움직임을 제한하여 업무의 효율성을 저하시킨 다. ${ }^{22,23}$ 처음부터 손상을 입은 후 급성염증이 완전한 치료가 되지 않 은 상태에서 훈련이 진행됨으로써 점차적으로 손상이 누적되며 반 복적으로 재발하는 만성염증으로 변화되었을 것으로 보인다.

손상의 재활방법에서 세 종목 운동선수는 모두 냉치료를 응급조 치로 많이 나타났다. 손상 발생 직후 급성염증기의 냉치료는 통증을 조절하고, 부종을 가라앉히는 효과적인 응급조치로서 각종 운동 손 상의 응급처치에 널리 사용되고 있다. 주요 치료 기관은 모두 병원이 많이 나타났다. 많은 운동선수가 전문적인 의료기관인 병원을 선택 하였으며 일차적인 치료를 병원에서 받는 것은 바람직한 현상이라는 것으로 생각하고 있었다. 치료형태로는 모두 외래치료이며, 치료기간 은 모두 1-2 주 가 많이 나타났다. 이는 많은 운동선수들이 장기간의 입원치료 보다 단기간의 효과가 빠른 증상 호전 목적 위주로 치료를 진행하고 있는 것으로 나타났다. 세 종목 선수들이 많이 이용하는 치 료방식은 물리치료로 $\mathrm{Kim}^{17}$ 의 테니스 운동선수를 대상으로 한 연구 와 일치하였다. 급성 부상 후 단지 증상 치료에 그치는 것이 아니라 기 능적 회복을 위한 재활에 대한 적절한 노력과 지원이 있어야 할 것으 로 사료된다.

본 연구의 결과를 통해 장애인 라켓 종목 운동 과정에서 손상과 재활에 대한 실업팀 운동선수들의 실태를 알 수 있다. 장애인 라켓 종목 즉 배드민턴, 탁구, 훨체어테니스 세 종목의 선수는 손상의 발생 실태와 급성 - 만성, 심각 정도, 증상 및 재활방법에서 큰 차이가 없었 고 주로 손상 부위 중 각 종목의 특성, 또는 특정한 기술적인 움직임 에 따라주요 손상부위에 차이가 있는 것이 확인되었다. 또한 본 연구 의 제한점을 보완하여 다양한 종목에서 발생할 수 있는 스포츠 손상
에 관하여 추가적으로 연구할 필요가 있으며, 이는 장애인 운동 선수 뿐만 아니라 생활체육으로써 운동을 즐기는 일반 장애인에게도 도 움이 될 것으로 사료된다.

\section{참고 문헌}

1. Korea Disabled Sports Association. Report on the survey on physical fitness for the disabled. Korea Disabled Sports Association. 2018.

2. Seo EC. Developing a scale for measuring the disability sports awareness through multi-paradigm of disability concept and latent variable modeling. Dankook University. Dissertation of Doctorate Degree. 2015.

3. Kim GE. The study of level of satisfaction on the sports-for-all project for the disabled in daegu and gyeongbuk regions. Daegu University. Dissertation of Master's Degree. 2011.

4. Park JD, Shin DC. Effects of daily life physical activities on the disabled' attitude and satisfaction. Korea sport research. 2004;15(6):777-89.

5. Song YH, Kim JC, Lee JA et al. Development of virtual reality-based visual perception and cognitive rehabilitation service. J Kor Phys Ther 2019;31(2):67-5.

6. Hyun JJ. Relationship between training anxiety and sports injuries of table player. Korean National University. Dissertation of Master's Degree. 1997.

7. Suk DH. Research on the wheelchair basketball player's sports injuries. Yong-In University. Dissertation of Master's Degree. 2002.

8. Park GH, Chang-sun Kim. Injuries type according to position in male high school hockey players. Journal of Coaching Development. 2009; 11(2):1-10.

9. Choi ET, Woo CM. A study on the frequency of injury in skill performance of golf. Korean journal of physical education. 2001;40:(1):327-38.

10. Lee SI, Park BS, Kim JH. Comparison and analysis for the injuries according to the golfers' level of function. Korea sport research. 2003;20(1): 1303-11.

11. Lee DS. The study on warm up and sports injuries in korea elite junior national badminton players. korean journal of sport science. 2012;21(4): 993-06.

12. Song CY. Analysis on the factors of sports injury in tennis. Chosun University. Dissertation of Master's Degree. 2002.

13. Lee NK. The study about table-tennis player's sports injuries. Seogang University. Dissertation of Master's Degree. 2001.

14. Choi DM. External injuries in sports factor of badminton player. Korea sport research. 2005;16(5):279-86.

15. Kim DM, Sung BJ, Yoon JH et al. Study on sports injuries in korea national badminton players. Journal of the Korea society for Wellness. 2013;8(2):143-53.

16. Kim DH. The comparative study of exercise induced injuries according to gender in middle and high school tennis players. Suwon University. Dissertation of Master's Degree. 1999.

17. Kim SW. The effects of basic physical fitness of tennis players on sports injuries. Dong-Eui University. Dissertation of Master's Degree. 2002.

18. Jung SY. Sports injuries of the adults badminton club. Korea National Sport University. Dissertation of Master's Degree. 2006.

19. Park JC, Park MS, Hwang TY. The effect of kinesio taping pre-interven- 
tion on delayed onset muscle soreness. J Kor Phys Ther. 2019;31(1):18-3.

20. Park KS, Jun TW, Baek SS et al. Clinical article : effect of badminton exercise on hematological indicators, morphological change of erythrocytes, and muscle damages. Korean Society of Sports Medicine. 2007; 25(2):223-9.

21. Kim BR, Kang TW. A systematic review of elastic taping effect of patients with stroke. J Kor Phys Ther. 2018;30(4):101-107.

22. Kim IG, Lee SY. The effect of forward head posture and tension type headache on neck movement: for office worker. J Kor Phys Ther. 2018; 30(4):108-11.

23. Kim MK, Lee WJ. Effect of fascial distortion model on the pain and movement of neck patient. J Kor Phys Ther. 2019;31(1):24-30. 